Volume 1 Nomor 2 Edisi Desember 2013
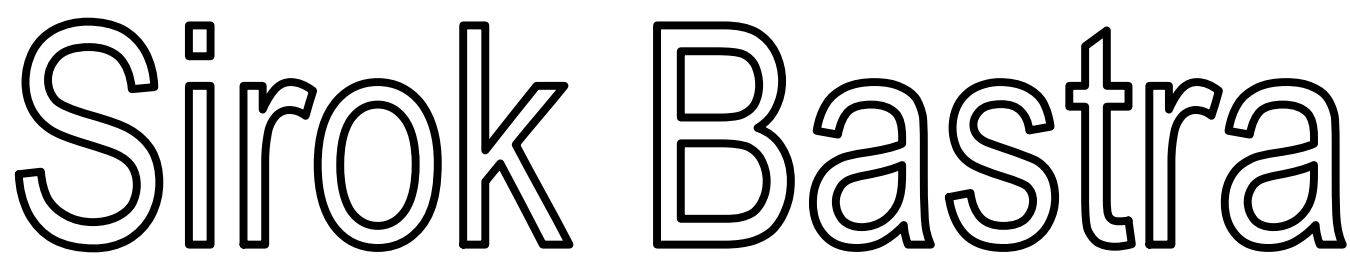

J URNAL ILMIAH KEBAHASAAN DAN KESASTRAAN

\begin{tabular}{|c|c|c|c|c|c|}
\hline $\begin{array}{c}\text { Sirok Bastra } \\
\text { Jurnal Kebahasaan dan } \\
\text { Kesastraan }\end{array}$ & Volume 1 & Nomor 2 & $\begin{array}{c}\text { Hlm. } \\
123-249\end{array}$ & $\begin{array}{c}\text { Pangkalpinang, } \\
\text { Desember } \\
2013\end{array}$ & $\begin{array}{c}\text { ISSN } \\
2354-7200\end{array}$ \\
\hline
\end{tabular}

KANTOR BAHASA KEPULAUAN BANGKA BELITUNG 

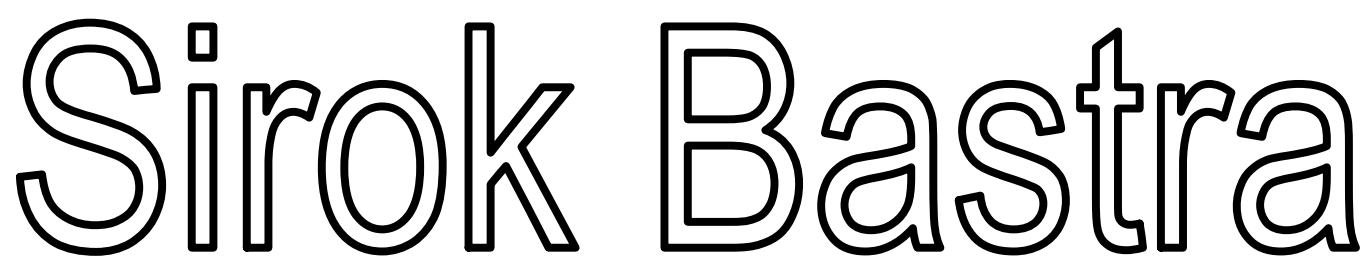

\section{J URNAL ILMIAH KEBAHASAAN DAN KESASTRAAN}

Jurnal ini merupakan wadah informasi mengenai kebahasan, kesastraan, dan pengajarannya yang memuat hasil penelitian, studi kepustakaan, dan tulisan ilmiah bidang kebahasan, kesastraan, dan pengajarannya. Jurnal ini terbit dua kali setahun, yakni Juni dan Desember, serta terbit sejak Juni 2013.

\section{Penanggung Jawab}

Kepala Kantor Bahasa Provinsi Bangka Belitung

Drs. Umar Solikhan, M.Hum.

\section{Mitra Bestari}

Prof. Dr. Agus Nuryatin, M.Hum. (Bidang Bahasa dan Pengajarannya)

Prof. Amrin Saragih, Ph.D., M.A. (Bidang Sastra dan Pengajarannya)

Dr. Felicia Nuradi Utorodewo, M.Hum. (Bidang Bahasa dan Pengajarannya)

Dr. Pujiharto, M.Hum. (Bidang Sastra dan Pengajarannya)

\section{Pemimpin Redaksi}

Rahmat Muhidin, S.S.

\section{Penyunting}

Prima Hariyanto, S.Hum.

\section{Perancang Sampul}

Feri Pristiawan, S.S.

\section{Kesekretariatan}

Khaliffitriansyah, S.Pd. Dea Letriana Cesaria, S.Hum.

Lia Aprilina, S.Pd.

Andrian Priyatno, A.Md.

Elzam

\section{Alamat Redaksi dan Penerbit}

Kantor Bahasa Provinsi Bangka Belitung

Ruko Permata 7, Jalan Solihin G.P. Km 4, Pangkalpinang, Kep. Bangka Belitung

Telp./Faks.: 0717-438455, Pos-el: sirokbastra@gmail.com

Pemuatan suatu tulisan dalam jurnal ini tidak berarti redaksi menyetujui isi tulisan tersebut. Isi tulisan menjadi tanggung jawab penulis. Tulisan telah ditinjau oleh mitra bestari. Setiap karangan dalam jurnal ini dapat diperbanyak setelah mendapat izin tertulis dari penulis, redaksi, dan penerbit. 


\section{KATA PENGANTAR}

Puji syukur ke hadirat Pemilik dan Pencipta semesta ini yang memiliki kuasa atas diri-Nya sendiri. Dialah Tuhan Yang Maha Esa yang telah memberikan rahmat dan hidayah-Nya sehingga Volume 1 Nomor 2 Jurnal Sirok Bastra dapat terbit tepat pada waktunya.

Pada nomor kedua ini, dimuat sebelas tulisan, yakni enam tulisan kebahasaan, empat kesastraan, dan satu pengajaran sastra. Dari segi bahasa, sebagian besar tulisan disajikan dalam bahasa Indonesia, hanya dua tulisan yang disajikan dalam bahasa Inggris. Kami mengucapkan terima kasih kepada para penulis yang telah bersedia menerbitkan karya mereka pada edisi ini. Para penulis merupakan para peneliti, pakar, dosen, dan mahasiswa dari berbagai perguruan tinggi dan instansi. Terima kasih juga kami sampaikan kepada para mitra bestari kami yang telah memberi ulasan terhadap tulisan-tulisan yang masuk ke redaksi.

Demi memenuhi keberagaman isi dan penulis, Sirok Bastra membuka kesempatan bagi para peneliti dan penulis menyampaikan hasil penelitian dan pemikiran mutakhir dalam bidang kebahasaan, kesastraan, dan pengajarannya.

Pangkalpinang, Desember 2013

Tim Redaksi 


\section{UCAPAN TERIMA KASIH UNTUK MITRA BESTARI}

Redaksi Sirok Bastra mengucapkan terima kasih kepada para mitra bestari yang telah meninjau, menimbang, dan mengulas makalah-makalah yang diterbitkan dalam Sirok Bastra Volume 1 Nomor 2, edisi Desember 2013, yakni

Prof. Dr. Agus Nuryatin, M.Hum.

Bidang Sastra dan Pengajarannya

Universitas Negeri Semarang

Semarang, Jawa Tengah

Prof. Amrin Saragih, Ph.D., M.A.

Bidang Bahasa dan Pengajarannya

Universitas Negeri Medan

Medan, Sumatra Utara

Dr. Felicia Nuradi Utorodewo, M.Hum.

Bidang Bahasa dan Pengajarannya

Universitas Indonesia

Depok, Jawa Barat

\section{Dr. Pujiharto, M.Hum.}

Bidang Sastra dan Pengajarannya

Universitas Gadjah Mada

Yogyakarta, Daerah Istimewa Yogyakarta 


\section{DAFTAR ISI}

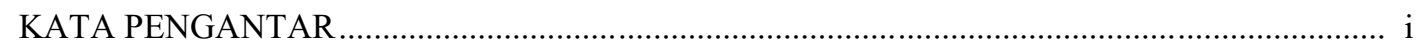

UCAPAN TERIMA KASIH UNTUK MITRA BESTARI .................................................... ii

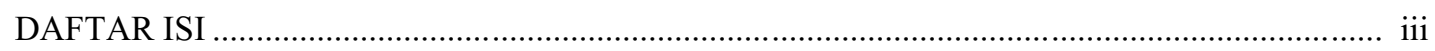

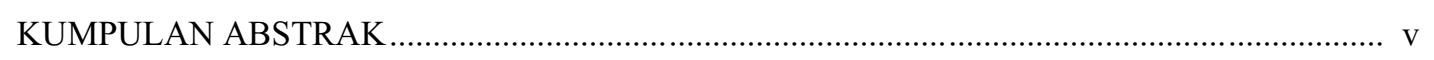

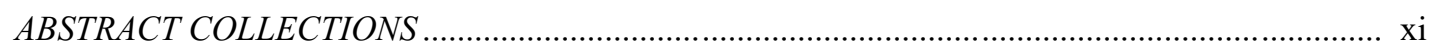

BAHASA INDONESIA DALAM INFORMASI DAN IKLAN DI RUANG PUBLIK KOTA PANGKALPINANG

(Indonesian in Information and Advertising in Public Space Pangkalpinang)

Umar Solikhan $123-129$

PERBEDAAN MAKNA NOMINA BERAFIKS $P E-, P E R-, P E--A N$, DAN $P E R--A N$ DALAM NASKAH HIKAYAT BAYAN BUDIMAN, HIKAYAT MUHAMMAD HANAFIYYAH, DAN HIKAYAT RAJA PASAI

(Affixed Noun Meaning Differences of pe-, per-, pe--an, and per--an in The Hikayat Bayan Budiman, Hikayat Muhammad Hanafiyyah, and Hikayat Raja Pasai Manuscripts)

Rindias H. Fatmasari $131-147$

WACANA RUBRIK INTIMATE DI MAJALAH DIGITAL INTERAKTIF MALE

(Intimate Rubric in Male Digital Interactive Magazine Discourse)

Prima Hariyanto $149-160$

AN ACOUSTICAL CONTRASTIVE ANALYSIS OF SUNDANESE CENTRAL VOWELS (Analisis Konstrastif Akustik Vokal Pusat Bahasa Sunda)

Yusup Irawan. $161-175$

KATA SUDAH SEBAGAI PENANDA ASPEK DENGAN AWALAN TER-

The Word of Sudah as An Aspect with Prefix Ter-

Dea Letriana Cesaria $177-182$

PERUBAHAN DAN PERGESERAN MAKNA DALAM KATA-KATA BERDERIVASI NOMINA KE VERBA YANG MENGANDUNG AFIKS $M E(N)-, M E(N)-K A N$, DAN $M E(N)-I$ PADA SURAT KABAR HARIAN KOMPAS

(Change and Shift of Meaning in The Derivated Words Nomine to Verb That Contain Affixes $m e(N)-$, me(N)-kan, dan me(N)- $i$ in The Kompas The Daily Newspaper)

Teodora Nirmala Fau $183-193$

MENCIPTA-KREATIF NASKAH DRAMA DENGAN STRATEGI MENULIS TERBIMBING (Creative Writing of Playscript eith Guided Writing Strategy)

Sony Sukmawan. $195-205$ 
PENGARUH KONSEP HAGABEON, HAMORAON, DAN HASANGAPON TERHADAP

KETIDAKSETARAAN GENDER DALAM AMANG PARSINUAN

(The Influence of Hagabeon, Hamoraon, and Hasangapon Concept for Gender Inequality in Amang Parsinuan)

Fransiska Simangunsong $207-220$

PERSPEKTIF PENGARANG MENGENAI RELASI ANTARA MANUSIA DAN

LINGKUNGAN HIDUP DALAM NOVEL PARTIKEL KARYA DEWI LESTARI: SEBUAH KAJIAN EKOKRITISISME

(Author's Perspective on The Relationship Between Humans and The Environment in The Novel Partikel Written by Dewi Lestari: an Ecocriticism Studies)

Alfi Yusrina Ramadhani $221-229$

FENOMENA HUKUM ADAT BALI TERHADAP BAYI KEMBAR BUNCING DALAM

NOVEL INCEST KARYA I WAYAN ARTIKA

Bali Custom Law Phenomenon of Kembar Buncing Infant in I Wayan Artika Novel Incest Annisa Aprinandri Irwin dan Khansa Khairunnisa $231-241$

RELIGIOUS AND MORAL VALUES IN MADURA FOLKTALES

Religiositas dan Nilai Moral dalam Cerita-Cerita Rakyat Madura

Imron Wakhid Harits. $243-249$ 


\title{
WACANA RUBRIK INTIMATE DI MAJALAH DIGITAL INTERAKTIF MALE
}

\section{Intimate Rubric in Male Digital Interactive Magazine Discourse}

Prima Hariyanto

Kantor Bahasa Provinsi Bangka Belitung

Ruko Permata No. 7, Jln. Solihin G.P. Km 4, Pangkalpinang

pos-el: patriyawhura@gmail.com

(diterima 23 Agustus 2013, disetujui 30 September 2013, revisi terakhir 25 Oktober 2013)

\begin{abstract}
Abstrak
Seiring dengan perkembangan ilmu pengetahuan dan teknologi, media massa pun berkembang dengan pesat. Kehadiran majalah digital memberi ruang kreasi baru bagi para pekerja media dan ruang informasi serta rekreasi baru bagi konsumennya. Majalah digital interaktif Male muncul sebagai majalah pria dewasa dengan ciri khas sensual. Artikel yang terdapat dalam rubrik Intimate memiliki struktur visual dan wacana yang menarik. Penelitian ini membahas struktur wacana teks rubrik Intimate di majalah digital interaktif Male. Penelitian ini menggunakan metode deskriptif dan teknik pengumpulan data menggunakan analisis kepustakaan. Penelitian ini membahas suprastruktur dan makrostruktur yang membangun wacana serta hubungan semantis antarunsur penyusun wacana yang menghasilkan kohesi dalam wacana tersebut.
\end{abstract}

Kata kunci: teks, suprastruktur, alat kohesi, makrostruktur

\begin{abstract}
Along with the development of science and technology, mass media have already grown rapidly. The presence of digital magazines provides new creative space for media workers and recreational space as well as new information for its consumers. Male interactive digital magazine emerged as adult men's magazine with a special feature sensual. Articles appearing in the Intimate section have a visual structure and interesting discourse. This research article discusses the rubric Intimate discourse structure in interactive digital magazine Male. This research used descriptive method and data collection techniques using literature analysis. This study discusses the developing superstructure and makrostruktur discourse and semantic relations discourse inter-element compilers that produce cohesion in discourse.
\end{abstract}

Key words: text, superstructure, cohesion makers, macrostructure

\section{PENDAHULUAN}

\subsection{Latar Belakang}

Ilmu pengetahuan dan teknologi semakin maju dan berkembang, termasuk dalam dunia media massa. Hal ini dapat dilihat dari semakin kreatifnya para aktor media dalam membuat produk sehingga memiliki bentuk dan penampilan yang lebih menarik para konsumen. Hal ini juga dipicu semakin ketatnya persaingan di dunia media massa sehingga memaksa produsen untuk terus berinovasi.

Media cetak semakin terpinggirkan oleh media elektronik yang selalu menyampaikan berita lebih instan. Akan tetapi, untuk menghindari hal tersebut, media cetak pun terus berinovasi. Beberapa media cetak mulai meninggalkan kertas sebagai medianya sehingga terlihat rancu dalam penamaan; tercetak tetapi tidak di atas kertas. Muncullah berbagai surat kabar, majalah, dan tabloid digital. Di antara mereka ada yang tetap mempertahankan wujud cetaknya di kertas selain juga bentuk digital berbayarnya. Namun, ada pula yang hanya menghadirkan wujud digitalnya, baik yang cuma-cuma maupun berbayar.

Salah satu majalah digital yang beredar adalah majalah pria dewasa Male. Majalah ini mengklaim dirinya sebagai majalah digital interaktif. Majalah mingguan ini pertama kali terbit pada 4 November 2012. Male adalah "majalah nyata" dari "majalah fantasi" dalam dunia Harry Potter, yakni Daily Propet. Sebagaimana Daily Propet, Male tidak hanya menyuguhkan gambar, tetapi juga audio dan audio visual. Inilah yang menarik dari majalah digital interaktif ini. Kekurangan Male adalah masih 
terbatasnya media yang dapat menyuguhkannya. Majalah ini baru dapat diakses melalui $\mathrm{iPad}^{1}$ dan tablet Android $^{2}$, sedangkan pengguna PC maupun komputer jinjing hanya dapat menikmati versi $\mathrm{PDF}^{3}$ nya saja.

Sebagaimana majalah pria dewasa lainnya yang berfokus pada gaya hidup pria, Male memiliki banyak rubrik yang menonjolkan sisi sensual. Di dalam majalah ini, terdapat pula rubrik Intimate, yakni rubrik yang membahas masalah-masalah seks. Artikel-artikel yang disuguhkan di rubrik ini tidak hanya mengungkapkan isu-isu seks yang sedang hangat, tetapi juga memberikan tips dan trik tentang seks dan kegiatannya. Artikel tersebut secara sekilas terlihat menarik dan terstruktur, baik dari penampilan maupun struktur wacananya. Oleh karena itu, dalam penelitian ini, penulis ingin membahas artikel dalam rubrik Intimate yang cukup menarik secara visual maupun wacana dengan menggunakan teori kajian wacana dilihat dari suprastruktur, hubungan semantis, dan makrostrukturnya.

\subsection{Masalah}

Berdasarkan pemaparan sebelumnya, masalah yang akan dibahas dalam penelitian ini adalah sebagai berikut.

a. Bagaimana suprastruktur wacana rubrik Intimate di majalah digital interaktif Male?

b. Bagaimana hubungan semantis antarunsur penyusun wacana yang menghasilkan kohesi dalam rubrik Intimate di majalah digital interaktif Male?

c. Bagaimana makrostruktur wacana rubrik Intimate di majalah digital interaktif Male?

\subsection{Tujuan}

Berdasarkan rumusan masalah tersebut, tujuan yang dicapai dalam penelitian ini adalah memaparkan suprastruktur wacana, hubungan semantis antarunsur penyusun wacana yang menghasilkan kohesi, dan makrostruktur wacana rubrik Intimate di majalah digital interaktif Male.

\subsection{Manfaat}

Penelitian ini dapat dimanfaatkan dalam kajian wacana dan media massa di Indonesia. Dalam kajian wacana, penelitian ini dapat memberikan gambaran deskriptif struktur wacana artikel di majalah pria dewasa. Sementara itu, bagi media massa, penelitian ini dapat memberikan manfaat bagi studi tentang penulisan artikel. Penelitian ini dapat membantu memberi masukan kepada penulis artikel dalam membuat tulisan agar mudah dipahami dan pesannya tersampaikan kepada pembaca.

\subsection{Metode dan Data}

Dalam penelitian ini, penulis menggunakan metode deskriptif, yaitu metode berdasarkan fakta yang ada atau fenomena yang secara empiris hidup pada pengguna-penggunanya. Dengan demikian, hasil yang diperoleh merupakan pemerian bahasa apa adanya secara terperinci dan mendalam (Sudaryanto, 1988: 62). Teknik kepustakaan digunakan untuk menganalisis data yang ditemukan agar dapat tercapai tujuan penelitian ini.

Korpus data yang digunakan dalam penelitian ini adalah majalah digital interaktif Male, khususnya rubrik Intimate, yakni rubrik yang membahas tentang seksualitas laki-laki maupun perempuan dan mencoba memberikan solusi atau tips untuk memecahkan permasalahan yang dipaparkan pada awal wacana rubrik tersebut. Adapun data yang digunakan adalah tiga teks yang dipilih secara acak dari edisi majalah Male yang telah terbit. Ketiga teks tersebut adalah (W1) "Quicky Sex, di Lift yang Paling Menantang" (Male edisi 004), (W2) "Morning Sex Picu Kebahagiaan" (Male edisi 007), dan (W3) "Sex in The Water Aktivitas Menyenangkan" (Male edisi 012). Untuk mempermudah penjelasan dalam bagian pembahasan hanya akan disebutkan kode ketiga wacana tersebut (W1, W2, dan W3).

\section{KERANGKA TEORI}

Menurut Hoed (1994:128), wacana merupakan bangun teoretis abstrak yang maknanya dikaji dalam kaitan dengan unsur-unsur lain di luar dirinya (dengan lingkungannya). Sebuah wacana dapat dikatakan sebagai wacana yang utuh apabila wacana tersebut kohesif dan koheren. Jenis-jenis wacana ada enam, yaitu tuturan, prosedur, pembeberan, pemerian, dorongan, dan percakapan (Larson, 1984:391). Menurut Larson (1984:391-392) dalam wacana tuturan, tujuan penulis adalah untuk menceritakan, wacana prosedur untuk memberi petunjuk, wacana pemerian untuk menerangkan dan memerikan, wacana 
dorongan untuk mengusulkan, menyarankan atau memerintah, dan wacana percakapan untuk menceritakan pergantian wicara.

Menurut Dijk (dalam Renkema, 1993:97), suprastruktur merupakan skema konvensional dari isi wacana yang dibahas dalam makrosktruktur. Suprastruktur merupakan kerangka suatu teks, alur teks, dan struktur skematik. Suprastruktur menggambarkan bentuk wacana yang berdiri di atas konten dalam arti tertentu.

Dijk memberikan contoh tingkatan struktur wacana berita. Struktur wacana berita Dijk diawali oleh headline, berbentuk judul yang merupakan garis besar atau ringkasan dari berita tersebut. Selanjutnya adalah lead, sebuah kalimat yang berisi esensi dari sebuah berita. Lead hampir sama dengan headline, hanya saja bentuknya kadang lebih panjang. Selanjutnya adalah flat text yang merupakan isi berita yang dijabarkan secara detil.

Menurut Halliday-Hasan (1976:4), konsep kohesi mengacu kepada hubungan makna yang ada dalam teks. Kohesi terjadi bila interpretasi suatu elemen dalam teks bergantung kepada elemen lainnya atau jika ada elemen yang mempraanggapkan dan elemen yang dipraanggapkan dalam teks itu. Kohesi merupakan taraf keterikatan antara satu proposisi dan proposisi lainnya di dalam sebuah wacana. Hubungan yang kohesif ditandai dengan adanya alat-alat kohesi, yakni referensi (pengacuan), substitusi (penggantian), elipsis (pelesapan), konjungsi, dan kohesi leksikal.

Makrostruktur merupakan makna global dari sebuah wacana (Renkema, 1993:94). Menurut Larson (1984), sebuah wacana, misalnya wacana tuturan, terbentuk dari bagian, gugus episode, episode, paragraf semantis, gugus proposisi, dan proposisi. Proposisi merupakan kombinasi konsep yang berhubungan satu sama lain sehingga hasilnya bermakna (Larson, 1984:269). Definisi proposisi adalah satuan semantis yang terdiri dari konsepkonsep. Konsep yang satu merupakan inti dan konsep lainnya berhubungan langsung dengan konsep inti (Larson, 1984:198).

Larson (1984:202) menjelaskan bahwa proposisi terdiri atas dua jenis utama, yaitu proposisi kejadian dan proposisi keadaan. Proposisi kejadian adalah proposisi yang memiliki konsep inti berupa kejadian. Konsep kejadian inti dalam proposisi kejadian dapat merujuk ke perbuatan, pengalaman, dan proses. Proposisi keadaan merupakan proposisi yang memiliki konsep inti berupa benda atau atribut.

\section{HASIL DAN PEMBAHASAN}

\subsection{Suprastruktur Wacana Rubrik Intimate di Majalah Male}

Suprastruktur ketiga wacana dalam rubrik Intimate tersebut diawali dengan headline (judul) dan elemen visual. Judul dari W1 adalah "Quicky Sex, di Lift yang Paling Menantang" dan terletak di bagian kiri atas artikel. Frase quicky sex ditulis dengan ukuran huruf besar dan judul selanjutnya lebih kecil. W2 berjudul "Morning Sex Picu Kebahagiaan" dan sangat menonjolkan kata sex karena ditulis dengan ukuran tiga kali lipat dari ukuran tulisan morning dan picu kebahagiaan. W3 berjudul "Sex in The Water Aktivitas Menyenangkan". Penulisan kedua unsur judul tersebut dipisahkan oleh gambar. Frase sex in the water yang ditulis dengan ukuran jumbo terletak di sisi kiri dan aktivitas menyenangkan berada di kanan atas dengan ukuran yang lebih kecil. Selain mempertimbangkan ukuran, penulisan ketiga judul tersebut juga memerhatikan kombinasi warna. Ketiganya mewakili tema dari wacana tersebut. Judul tersebut akan menggiring pembaca agar meneruskan membaca keseluruhan isi wacana.

Selain judul, terdapat pulau elemen visual berupa foto yang mendukung dan menggambarkan isi wacana. Dalam W1 satu foto pasutri yang mengesankan sedang melakukan quicky sex dan satu foto paha dan kaki seorang perempuan. Dalam W2 terdapat dua foto pasutri di atas ranjang dengan hanya tertutup selimut. Dalam W3 terdapat dua foto pasutri dalam kondisi basah dengan pakaian minim.

Selanjutnya adalah bagian lead-in yang membuka artikel. Bagian ini ditulis dengan ukuran huruf yang lebih besar daripada tubuh wacana dan berisi pembuka untuk mengantarkan ke isi wacana. Selain berisi pendahuluan, bagian ini juga dapat berisi pengertian mengenai tema utama yang dibahas dalam wacana tersebut. Sebagai contoh dalam lead-in W1 berisi pengertian quicky sex.

Bagian berikutnya adalah isi atau tubuh wacana. Selain sudah diberikan pengantar pada bagian lead-in, pada bagian awal tubuh wacana juga sedikit diberi pengantar lagi. Pada paragraf pertama sampai kedua, 
umumnya dipaparkan contoh kondisi yang melatarbelakangi mengapa terjadi seperti yang digambarkan dalam tubuh wacana. Pengantar ini diperlukan untuk memberikan pengertian karena tidak semua pembaca paham dengan istilah atau keadaan yang dipaparkan di dalamnya.

Selain dibuat narasi, tubuh wacana juga dibuat per poin. Hal ini sangat memudahkan pembaca, apalagi jika yang dipaparkan berupa penjelasan yang memang perlu perincian. Sebagai contoh, dalam W1 diperinci berbagai tempat dan posisi yang cocok untuk setiap tempat dalam melakukan quicky sex. Dalam W2 dan W3, diperinci berbagai posisi yang nyaman dan mungkin dapat dilakukan ketika melakukan aktivitas morning sex dan sex in the water.

\subsection{Kohesi Wacana Rubrik Intimate di Majalah Male}

Di dalam ketiga artikel yang diambil sebagai data, ditemukan beberapa alat kohesi yang menandai hubungan yang kohesif. Untuk mempermudah analisis, setiap kalimat diberi nomor sesuai wacananya, misalnya (2.7) berarti kalimat ketujuh dari wacana kedua (W2). Adapun alat kohesi yang ditemukan adalah sebagai berikut.

\subsubsection{Referensi (Pengacuan)}

Referensi merupakan alat kohesi yang penafsiran salah satu unsurnya mengacu pada unsur yang lain, baik di dalam maupun di luar teks. Jika unsur yang diacu (antesenden) ada di dalam teks (bersifat tekstual) disebut endofora; jika di luar teks disebut eksofora. Di dalam data ditemukan beberapa contoh referensi sebagai berikut.

(1.3) Bagi lelaki, untuk membangkitkan gairah seks, ia tak harus membutuhkan waktu yang lama seperti yang dialami oleh kaum perempuan.

(1.20) Kemudian, lakukan penetrasi dengan cepat dan saat telah melakukannya, lepaskan tangan dari tombol "menutup", lalu biarkan lift kembali bergerak.

Kedua kalimat tersebut merupakan contoh penggunaan alat kohesi referensi endofora. Referensi endofora dibagi lagi menjadi dua, yaitu anaforis (antesendennya sudah muncul lebih dulu) dan kataforis (antesenden muncul di belakang; acuan mengikuti pengacu). Kalimat (1.3) dan (1.20) menggunakan referensi anaforis. Kata ia dalam kalimat (1.3) mengacu pada kata lelaki, sedangkan bentuk terikat -nya pada kata melakukannya dalam kalimat (1.20) mengacu pada kata penetrasi.

Selain termasuk anaforis, kata ia dalam kalimat (1.3) juga merupakan contoh referensi personal, yakni referensi yang menggunakan pronomina persona untuk menggantikan kata yang diacu. Referensi personal ditandai dengan penggunaan pronoun dan determiners yang biasanya mengacu pada individu atau benda yang disebutkan dalam teks (Halliday dan Hasan, 1976: 37).

(2.21) Posisi ini akan sangat mudah untuk menstimulasi G-spot.

(3.21) Posisi ini sangat nyaman jika dilakukan di bath tub yang bisa dilakukan secara bergantian.

(2.25) Posisi klasik ini juga membuat Anda dan pasangan bisa terus berdekatan dan berpelukan hangat.

Berbeda dengan dua kalimat sebelumnya yang antesendennya berada dalam kalimat yang sama, antesenden ketiga kalimat ini berada pada kalimat sebelum-sebelumnya. Kata ini dalam kalimat (2.21) mengacu pada doggy style, ini pada kalimat (3.21) mengacu pada terlentang, dan ini pada kalimat (2.25) mengacu pada posisi misionaris. Ketiga pengacuan tersebut tidak dapat ditemukan di dalam kalimat, tetapi di kalimat sebelumnya sehingga kalimat tersebut tidak dapat berdiri sendiri sebagai wacana, harus dirangkai dengan kalimat lain agar utuh dan dapat dipahami.

\subsubsection{Substitusi (Penggantian)}

Substitusi adalah penggantian suatu unsur bahasa dengan unsur bahasa lain. Substitusi berfungsi untuk menghindari terjadinya pengulangan dari kata yang sama. (Halliday dan Hassan, 1976: 88). Kelas kata yang digantikan yang sama dengan kata yang digantikan. Namun, maknanya dapat sama sekali berbeda dengan kata yang dirujuk. Berikut ini adalah beberapa contoh substitusi yang ditemukan dalam data.

(1.18) Elevator atau lift adalah lokasi seks kilat yang paling menantang, meskipun naik atau turun beberapa lantai tidak cukup waktu untuk bercinta. (1.19) Triknya, perlambat laju lift dengan terus menekan tombol "menutup".

Pada kalimat (1.18), unsur yang disubstitusikan adalah klausa elevator atau lift adalah lokasi seks 
kilat yang paling menantang, digantikan dengan -nya pada kata triknya dalam kalimat (1.19). Data di atas menunjukkan bahwa kalimat tersebut mengandung subtitusi klausal karena unsur yang disubstitusikan berupa klausa.

(2.2) Morning erection adalah saat Mr. P memiliki ukuran yang jauh lebih besar dari biasanya. (2.3) Pada saat itulah kadar hormon seks testosteron pada laki-laki meningkat.

Pada kalimat (2.2), unsur yang disubstitusikan adalah morning erection, digantikan dengan kata itulah pada kalimat (2.3). Dengan demikian, data di atas menunjukkan bahwa kalimat tersebut mengandung substitusi nominal karena unsur yang disubstitusikan berupa kata benda (nomina).

(2.13) Coba lakukan seks di pagi hari secara spontan, tanpa persiapan. (2.14) Hal ini akan membuat Anda lebih bahagia dan mampu menghilangkan depresi.

Pada kalimat (2.13), unsur yang disubstitusikan adalah coba lakukan seks di pagi hari, digantikan dengan frasa hal ini pada kalimat (2.14). Data di atas menunjukkan bahwa kalimat tersebut mengandung substitusi verbal karena unsur yang disubstitusikan adalah kata kerja (verba).

\subsubsection{Elipsis (Pelesapan)}

Elipsis merupakan proses penghilangan kata atau satuan lain yang bentuk asalnya dapat diramalkan dari konteks bahasa tersebut. Unsur yang lesap tersebut dapat ditelusuri keberadaannya pada bagian sebelum atau sesudahnya. Elipsis ditandai dengan $\varnothing$ (Halliday dan Hassan, 1976: 146). Berikut ini adalah beberapa contoh elipsis yang ditemukan dalam data.

(2.21) Posisi ini akan sangat mudah untuk menstimulasi G-spot. (2.22) Gunakan $\varnothing$ untuk menstimulasi daerah sensitif pasangan.

Pada data di atas, unsur yang dilesapkan adalah frasa posisi ini. Dengan demikian, data di atas merupakan contoh elipsis nominal karena yang dilesapkan termasuk kata benda (nomina).

(3.2) Melakukan kegiatan seks di dalam air sah-sah saja. (3.3) Secara medis pun $\varnothing$ tergolong aman.

Pada data di atas, unsur yang dilesapkan adalah melakukan kegiatan seks di dalam air. Dengan demikian, data di atas merupakan contoh elipsis verbal karena yang dilesapkan termasuk kata kerja (verba).

(1.11) Berdua bisa saling membantu bila ada pihak yang belum terangsang secara cepat. (1.12) Setelah usai $\varnothing$, sisakan waktu beberapa saat untuk dinikmati bersama.

Pada data di atas, unsur yang dilesapkan adalah berdua bisa saling membantu. Dengan demikian, data di atas merupakan contoh elipsis klausal karena yang dilesapkan berupa klausa.

\subsubsection{Konjungsi}

Konjungsi adalah kata atau gabungan kata yang berfungsi menghubungkan bagian-bagian ujaran yang mungkin berupa kata dengan kata, frase dengan frase, klausa dengan klausa, maupun kalimat dengan kalimat. Menurut Halliday dan Hasan (1976: 238), konjungsi terdiri dari empat jenis, yakni adversatif (pertentangan), aditif (penambahan), temporal (urutan waktu), dan kausal (sebab akibat).

\section{a. Adversatif}

Konjungsi adversatif merupakan konjungsi yang memarkahi makna yang berhubungan dengan pertentangan atau perbedaan yang berupa pertentangan (bahkan, akan tetapi, namun), kebalikan (sebaliknya, padahal), dan perbandingan (sedangkan). Di bawah ini adalah beberapa contoh konjungsi adversatif yang ditemukan dalam data.

(3.26) [Tapi] khusus untuk pantai dan kolam renang ada hal yang harus Anda perhatikan, yakni sisi keamanan.

(3.27) [Sedangkan] untuk kolam renang tentu tidak akan menjadi masalah jika dilakukan di kolam renang pribadi.

(2.17) Posisi pria memeluk si wanita dari belakang, hampir seperti Doggy Style, [namun] dalam posisi berbaring.

(1.4) [Meski] namanya seks cepat atau seks kilat, bukan berarti tanpa foreplay.

(1.18) Elevator atau lift adalah lokasi seks kilat yang paling menantang, [meskipun] naik atau turun beberapa lantai tidak cukup waktu untuk bercinta.

Konjungsi tapi dan sedangkan adalah konjungsi antarklausa yang tidak dapat diletakkan pada awal kalimat. Kedua konjungsi ini seharusnya berada di tengah kalimat untuk 
menghubungkan klausa yang satu dengan lainnya yang setara. Oleh karena itu, kalimat 3.26 dan 3.27 perlu diperbaiki. Sebaliknya, konjungsi namun merupakan konjungsi antarkalimat sehingga tidak dapat berada di dalam tengah kalimat untuk menghubungkan klausa. Dengan demikian, namun dalam kalimat 2.17 seharusnya diganti dengan konjungsi pertentangan antarklausa.

\section{b. Aditif}

Konjungsi aditif adalah konjungsi yang memarkahi makna yang berhubungan dengan keterangan tambahan yang berupa urutan (kemudian, selanjutnya), gabungan (dan kemudian, juga, selain itu, serta), beberan (bahwa, artinya, adapun), dan contoh (dan misalnya, sebagai contoh). Beberapa contoh konjungsi aditif yang ditemukan dalam data dapat dilihat di bawah ini.

(1.22) [Dan] selama beraksi, minta ia untuk terus menekan tombol lift.

(3.19) Anda dapat mengangkat tubuhnya [dan] biarkan kedua kakinya melilit pinggang Anda.

(2.14) Hal ini akan membuat Anda lebih bahagia [dan] mampu menghilangkan depresi.

(2.9) Konon dengan morning sex, Anda dapat mengawali hari dengan perasaan happy, positive thinking, [dan] wajah berseri-seri.

\section{c. Temporal}

Konjungsi temporal adalah konjungsi yang memarkahi makna yang berhubungan dengan waktu, baik sebelum, bersamaan, maupun setelahnya. Beberapa contoh konjungsi temporal yang ditemukan dalam data dapat dilihat di bawah ini.

(1.12) [Setelah] usai, sisakan waktu beberapa saat untuk dinikmati bersama.

(1.20) [Kemudian], lakukan penetrasi dengan cepat dan saat telah melakukannya, lepaskan tangan dari tombol "menutup", [lalu] biarkan lift kembali bergerak.

(2.20) Pasangan cukup bertumpu pada lengan dan kaki, [sementara] Anda melakukan penetrasi dengan kecepatan yang dapat disesuaikan.

(3.8) Untuk lebih memberikan stimulasi atau fareplay pada tempat yang kering [sebelum] Anda memulai petualangan aktivitas seks ini.

(1.25) Saat di dressing room, [ketika] pasangan wanita tengah menjajal busana yang ingin dibelinya di fitting atau dressing room, bisa dimanfaatkannya untuk seks kilat.

\section{d. Kausal}

Konjungsi kausal merupakan konjungsi yang memarkahi makna yang berhubungan dengan sebab akibat yang berupa persyaratan (jika, bila, kalau), alasan (karena), simpulan (jadi, dengan demikian), dan akibat (sehingga, maka, karena itu). Beberapa contoh konjungsi kausal yang ditemukan dalam data dapat dilihat di bawah ini.

(3.14) Hati-hati bila mengambil posisi, [karena] posisi seks yang salah justru dapat mengurangi kenikmatan.

(3.4) Dari sisi ms. V secara alami memiliki "anti virus" [sehingga] kuman tidak masuk pada saat melakukan hubungan seks.

(2.24) Posisi misionaris jadi favorit [karena] banyak orang menganggap itulah cara bercinta yang sebenarnya.

(1.32) Selain itu bisa menganakan dress, [maka] tak perlu repot-repot membuka celana.

(1.14) [Karena] tidak adanya pemanasan [maka] bagian sensitif perlu mendapat perhatian yang paling intens.

\subsubsection{Kohesi Leksikal}

Kohesi leksikal dapat terjadi ketika dua buah kata dalam sebuah teks berhubungan secara semantis. Kohesi leksikal menghubungkan kalimat-kalimat di dalam sebuah wacana melalui pemilihan kata. Menurut Yuwono (dalam Kushartanti [ed.], 2007) kohesi leksikal diwujudkan dengan reiterasi dan kolokasi. Reiterasi merupakan pengulangan kata-kata pada kalimat berikutnya untuk memberikan penekanan bahwa kata-kata tersebut merupakan fokus pembicaraan. Wujud reiterasi berupa repetisi, sinonimi, hiponimi, metonimi, dan antonimi. Adapun kolokasi adalah hubungan antarkata yang berada pada lingkungan atau bidang yang sama.

\section{a. Repetisi}

Contoh repetisi yang ditemukan dalam data dapat dilihat dalam kutipan di bawah ini.

Quicky sex atau seks kilat adalah berhubungan seks dalam waktu yang singkat. Bagi lelaki, untuk membangkitkan gairah seks, ia tak harus membutuhkan waktu yang lama seperti yang dialami oleh kaum perempuan. Meski namanya seks cepat atau seks kilat, bukan berarti tanpa foreplay. Tidak 
sehat sebuah aktivitas seks yang dilakukan tanpa pemanasan terlebih dahulu.

Kutipan di atas diambil dari teks pertama. Berdasarkan kutipan tersebut, dapat dilihat bahwa terdapat bentuk kohesi leksikal berupa repetisi. Bentuk yang diulang adalah kata seks. Hal ini tentu saja sangat berkaitan dengan tema wacana maupun tema besar dalam rubrik Intimate di majalah ini. Repetisi ini dapat mengaitkan sebuah kalimat dengan kalimat lain yang bagiannya mengalami pengulangan.

\section{b. Sinonimi}

Contoh sinonimi yang ditemukan dalam data dapat dilihat dalam kutipan di bawah ini.

(1.18) Elevator atau lift adalah lokasi seks kilat yang paling menantang, meskipun naik atau turun beberapa lantai tidak cukup waktu untuk bercinta.

(1.24) Posisi bercinta yang ideal di dalam mobil adalah gaya missionary atau woman on top.

(1.25) Saat di dressing room, ketika pasangan wanita tengah menjajal busana yang ingin dibelinya di fitting atau dressing room, bisa dimanfaatkannya untuk seks kilat.

Sinonim atau padanan makna bentuk bahasa dapat ditemukan dalam ketiga kalimat di atas. Umumnya, di dalam data, sinonim yang muncul merupakan bahasa asing yang disandingkan dengan padanannya dalam bahasa Indonesia atau bahasa asing yang disandingkan dengan padanannya dalam bahasa asing pula. Kalimat 1.24 (missionary atau woman on top) dan 1.25 (fitting atau dressing room) merupakan contoh padanan yang keduanya dalam bahasa asing. Sedikit ditemukan sinonim yang keduanya merupakan bahasa Indonesia. Kalimat 1.18 (elevator atau lift) adalah contoh padanan yang keduanya dalam bahasa Indonesia.

\section{c. Hiponimi}

Contoh hiponimi yang ditemukan dalam data dapat dilihat dalam kutipan di bawah ini.

(1.6) [Pemanasan] tetap harus dilakukan, semisal [bercumbu], [rangsangan pada bagian sensitif] dan sebagainya.

(1.17) Bahkan ada pasangan yang melakukannya di [tempat umum], seperti di [mobil], di [ruangan kantor], [toilet umum], [elevator], dan sebagainya.
Dalam kalimat 1.6, hubungan hiponimi terdapat dalam kata/frase bercumbu dan rangsangan pada bagian sensitif yang merupakan hiponim dari kata pemanasan. Adapun dalam kalimat 1.17 kata/frase mobil, ruangan kantor, toilet umum, dan elevator merupakan hiponim dari frase tempat umum.

\section{d. Antonimi}

Umumnya antonimi di dalam data berada dalam kalimat majemuk setara hubungan pertentangan. Hal yang dipertentangkan (antonimi) pun berupa frase atau klausa. Namun, ada juga bentuk antonimi berupa kata atau di luar kalimat majemuk hubungan pertentangan. Contoh antonimi yang ditemukan dalam data dapat dilihat dalam kutipan di bawah ini.

(1.18) Elevator atau lift adalah lokasi seks kilat yang paling menantang, meskipun [naik] atau [turun] beberapa lantai tidak cukup waktu untuk bercinta.

(2.18) Posisi ini memungkinkan pasangan untuk lebih santai dan [tidak banyak bergerak] dan Anda dapat lebih [aktif].

\section{e. Kolokasi}

Contoh kolokasi yang ditemukan dalam data dapat dilihat dalam kutipan di bawah ini.

(3.19) Anda dapat mengangkat [tubuh]nya dan biarkan kedua [kaki]nya melilit [pinggang] Anda.

(1.16) Bebarapa tempat yang paling dapat dilakukan quicky sex misalnya di [bathroom], di [taman belakang rumah], [dapur], [loteng rumah], [kolam renang] dan sofa.

Kolokasi banyak ditemukan dalam kalimat atau wacana yang memberikan pemerian, seperti dalam kalimat 1.16. Namun, sebuah wacana yang baik pasti juga memiliki kolokasi. Beberapa kata dalam wacana tersebut pasti berada dalam bidang atau lingkungan yang sama karena berada dalam satu tema. Jika tidak ditemukan kolokasi, ada sesuatu dalam wacana tersebut karena tidak mungkin jika dalam satu tema ada penjelasan yang tidak berhubungan atau berada dalam bidang/lingkungan yang sama.

Di dalam data, banyak ditemukan kata yang berada dalam bidang dan lingkungan seksualitas. Hal ini sesuai dengan tema dan topik yang 
diangkat dalam wacana tersebut. Akan tetapi, kita juga dapat menemukan kolokasi yang agak berjarak (hubungannya tidak langsung) dengan seksualitas. Kalimat 3.19 merupakan salah satu contoh kolokasi dalam bidang anggota tubuh.

\subsection{Makrostruktur Wacana Rubrik Intimate di Majalah Male}

Makrostruktur merupakan makna global wacana dan menyangkut tentang isi wacana. Karena keterbatasan ruang, dalam makalah ini hanya dipaparkan gambaran umum salah satu makrostruktur artikel saja, yakni wacana kedua yang berjudul "Morning Sex Picu Kebahagiaan". Pada dasarnya, ketiga wacana yang dijadikan data pada makalah ini memiliki makrostruktur berupa bagian pembuka (tema) dan bagian batang tubuh (topik) yang terdiri dari latar, masalah, jalan keluar, dan pemecahan. Mengingat keterbatasan ruang pula, penjelasan utama analisis saya disajikan dalam bagan, sedangkan deskripsi di bawahnya hanya penjelasan secara garis besar. Secara terperinci justru terdapat dalam bagan.

\subsubsection{Bagian Pembuka (Tema)}

tema — (1) morning sex picu kebahagiaan

Bagian pembuka (tema) dalam wacana ini diambil dari judul artikel, yakni "Morning Sex Picu Kebahagiaan". Tema ini akan dijelaskan pada proposisi-proposisi berikutnya terutama pada gugus proposisi 17-26 yang menyatakan bahwa morning sex dapat membuat pelakukanya mengawali hari dengan perasaan happy, positive thinking, wajah berseri, lebih bersemangat, menguatkan sistem imunitas, dan memberikan rasa bahagia.

\subsubsection{Bagian Batang Tubuh (Topik)}

Topik dari teks “Morning Sex Picu Kebahagiaan" adalah kegiatan hubungan seksual pada pagi hari. Dalam teks ini dikatakan bahwa kondisi hormon testosteron meningkat sehingga sebaiknya dimanfaatkan. Selain itu, morning sex juga memiliki manfaat yang cukup banyak bagi kondisi tubuh. Untuk menghindari kebosanan, diberikan beberapa variasi seks sebagai alternatif morning sex. Bagian semantis ini dibagi menjadi empat bagian, yakni latar, masalah, jalan keluar, dan pemecahan yang akan dijabarkan dalam bagan sebagai berikut.

\subsubsection{Latar}

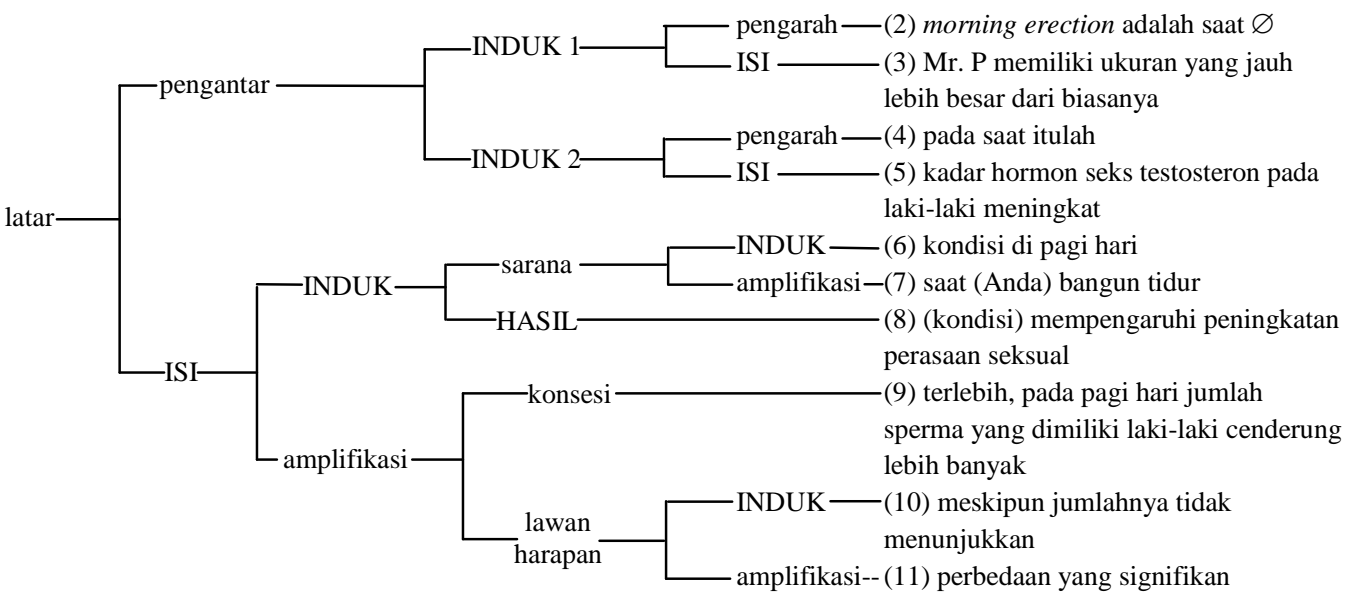

Bagian latar dalam bagan makrostruktur ini terbagi menjadi dua, yakni pengantar dan isi. Pengantar dibagi lagi dalam dua induk yang setara, sedangkan isi dibagi menjadi induk dan amplifikasi.
Sepuluh proposisi tersebut disatukan melalui dua jenis hubungan, yakni pengarah-ISI dan INDUKamplifikasi. 


\subsubsection{Masalah}

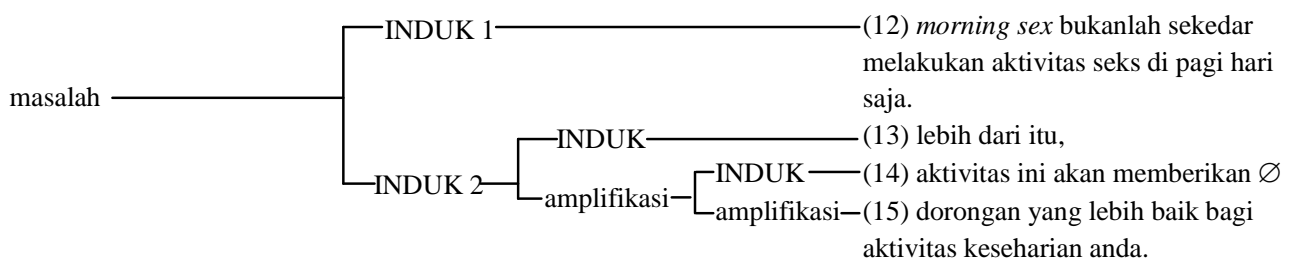

Bagian masalah dalam bagan makrostruktur ini dibagi menjadi dua induk. Induk 1 terdiri dari satu satuan (INDUK-amplifikasi) dan terdiri dari tiga proposisi. proposisi, sedangkan induk dua dibagi menjadi dua

\subsubsection{Jalan Keluar}

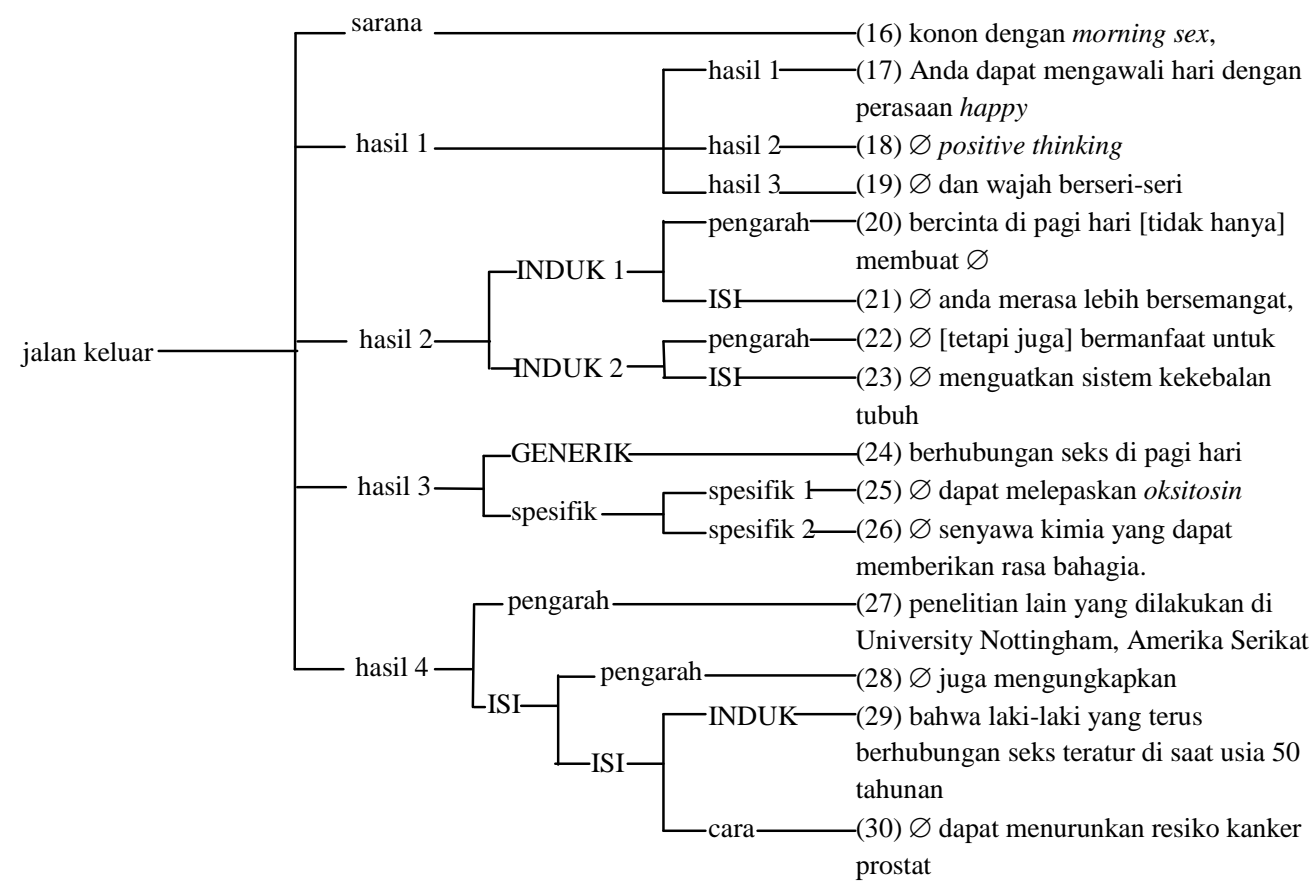

Bagian jalan keluar yang terdiri dari lima belas proposisi dibagi dalam lima bagian, yakni sarana dan hasil (1-4). Hubungan sarana-hasil menunjukkan bahwa ada sesuatu (proposisi 16) yang menghasilkan/menyebabkan sesuatu lainnya (proposisi 17-30). Sarana terdiri dari satu proposisi. Hasil 1 terdiri dari tiga proposisi yang disatukan dalam hubungan hasil-hasil. Hasil 2 terdiri dari empat proposisi yang dihubungkan dalam hubungan indukinduk; kedua induk terdiri dari dua proposisi dengan hubungan pengarah-ISI. Hasil 3 terdiri dari tiga proposisi yang dihubungkan dalam hubungan GENERIK-spesifik. Hasil 4 terdiri dari empat proposisi yang dihubungkan dalam hubungan pengarah-ISI. 


\subsubsection{Pemecahan}

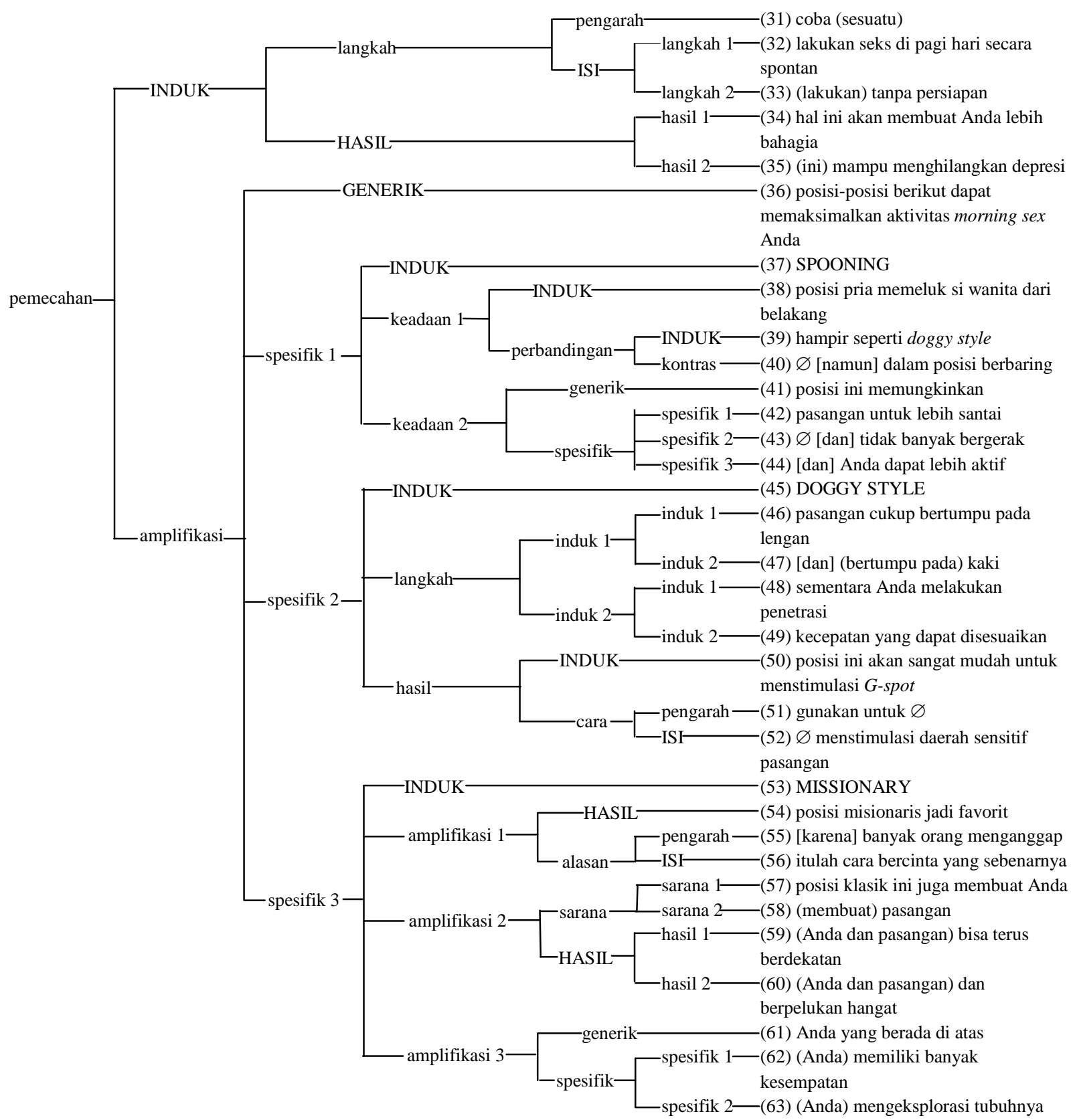

Bagian pemecahan yang terdiri dari 33 proposisi ini dibagi ke dalam dua bagian dalam hubungan INDUK-amplifikasi. Hubungan ini menunjukkan bahwa salah satu bagian menyampaikan semua informasi yang sudah terdapat dalam satuan lainnya, bersama dengan informasi tambahan.

Gugus INDUK yang terdiri dari lima proposisi disatukan dalam hubungan LANGKAH-hasil. Proposisi 32-33 dengan hubungan langkah-langkah dan keduanya disatukan dengan proposisi 31 melalui hubungan pengarah-ISI.

Gugus amplifikasi disatukan dalam hubungan GENERIK-spesifik. Generik hanya terdiri dari satu proposisi (36). Adapun spesifik terdiri dari tiga bagian. Dalam spesifik 1, terdapat hubungan indukkeadaan, spesifik 2 INDUK-langkah-HASIL, dan spesifik 3 INDUK-amplifikasi.

\section{SIMPULAN}

Berdasarkan analisis yang telah dilakukan, dapat disimpulkan bahwa suprastruktur yang ada di wacana rubrik Intimate terdiri dari empat bagian, yakni headline (judul), elemen visual, lead-in, dan isi atau tubuh wacana. Penulisan judul dalam wacana tersebut memperhatikan ukuran, warna, dan jenis huruf. Judul yang digunakan mewakili keseluruhan isi wacana. 
Elemen visual cukup penting perannya karena menjadi bahan penarik bagi pembaca, yakni gambargambar romantis, sensual, bahkan erotis. Lead-in ditulis untuk membuka artikel. Penulisannya menggunakan huruf dengan ukuran lebih besar daripada isi wacananya. Bagian terakhir adalah isi/tubuh wacana. Meskipun sudah diberikan pengantar pada lead-in, di awal tubuh wacana juga diberi sedikit pengantar lagi. Umumnya, wacana rubrik Intimate berisi latar belakang, penjelasan istilah atau keadaan yang dipaparkan di dalamnya, narasi, dan juga tubuh wacana yang dibuat per poin.

Kohesi yang terdapat dalam wacana rubrik Intimate adalah referensi, substitusi, elipsis, konjungsi, serta kohesi leksikal. Adapun konjungsi yang digunakan adalah konjungsi adversatif, aditif, temporal, dan kausal. Kohesi leksikal yang ditemukan adalah repetisi, sinonimi, hiponimi, antonimi, dan kolokasi, sedangkan metonimi tidak ditemukan dalam data.

Pada dasarnya, ketiga wacana yang dijadikan data pada makalah ini memiliki makrostruktur berupa bagian pembuka (tema) dan bagian batang tubuh (topik) yang terdiri dari latar, masalah, jalan keluar, dan pemecahan. Seluruh proposisi yang ada di dalam teks disatukan dalam berbagai hubungan yang tentu saja menjadikan teks kohesif dan koheren. Hubungan tersebut adalah INDUK-amplifikasi, pengarah-ISI, sarana-HASIL, pengantar-ISI, GENERIK-spesifik, spesifik-spesifik, langkah-HASIL, langkah-langkah, hasil-hasil, induk-induk, INDUK-keadaan, HASIL- alasan, INDUK-cara, INDUK-kontras, INDUKperbandingan, dan konsesi-lawan harapan.

Dengan demikian, teks yang disajikan dalam rubrik Intimate majalah Male tidak hanya mengandalkan materi yang berupa seksualitas yang memang sudah menarik banyak perhatian pembaca, tetapi juga penyajiannya yang sangat menarik dan memerhatikan prinsip-prinsip pembentukan wacana yang baik dan mudah dipahami oleh pembaca.

Secara linguistik, khususnya wacana, teks yang disajikan dalam rubrik Intimate sudah cukup baik. Bagian-bagian yang penting dari sebuah wacana sudah ada di dalamnya sehingga pembaca semakin mudah untuk memahaminya. Meskipun banyak memunculkan istilah kurang populer bagi pembaca awam, teks tersebut masih dapat dipahami karena diberi latar belakang dan penjelasan istilah serta narasi. Alat-alat kohesi yang digunakan pun sangat membantu pembaca dalam memahami pesan. Makrostruktur yang membentuk teks tersebut juga terstruktur dan hubungan antarbagiannya koheren, tidak asal selesai.

Beberapa hal yang perlu diperbaiki adalah mengenai kebakuan diksi dan ejaannya. Masih sering ditemukan kata-kata yang tidak sesuai kaidah bahasa Indonesia dan ejaannya pun kadang masih belum sesuai. Di sinilah peran penyunting yang harus dilibatkan. Bagi pembaca, hal-hal semacam ini memang tidak mengganggu, tetapi akan lebih baik jika yang seperti ini juga diperhatikan demi kesempurnaan sebuah teks.

\section{CATATAN BELAKANG}

1) iPad adalah produk tablet komputer keluaran Apple.

2) Android Inc. adalah sebuah perusahaan software kecil yang didirikan pada bulan Oktober 2003 di Palo Alto, California, USA. Didirikan oleh beberapa senior di beberapa perusahaan yang berbasis IT and Communication, yakni Andy Rubin, Rich Miner, Nick Sears, dan Chris White. Konsep yang dimiliki Android Inc. ternyata menggugah minat perusahaan raksasa Google untuk memilikinya. Pada bulan Agustus 2005, Android Inc. diakuisisi oleh Google Inc. Seluruh sahamnya dibeli oleh Google. Andy Rubin, Rich Miner, Nick Sears, dan Chris White tetap di Android Inc. yang dibeli Google sehingga akhirnya mereka semua menjadi bagian dari raksasa Google dan sejarah Android. Saat itulah, mereka mulai menggunakan platform linux untuk membuat sistem operasi bagi mobile phone sehingga dapat digunakan di telepon genggam dan komputer tablet (http://aplikasiandroid.com/berita-android-2/sejarah-android-os/).

3) PDF (portable document format) adalah format berkas yang dibuat oleh Adobe Systems pada tahun 1993 untuk keperluan dokumen digital (http://id.wikipedia.org/). Dokumen berformat PDF dapat dilihat dan dicetak dalam berbagai sistem operasi komputer secara konsisten tanpa perubahan layout. Untuk membacanya, digunakan software PDF Reader, seperti Adobe Acrobat Reader (www.smitdev.com). 


\section{DAFTAR PUSTAKA}

Abdul Rani, Bustanul Arifin, dan Martutik. 2006. Analisis Wacana. Malang: Bayumedia Publishing.

Alek dan H.P Achmad. 2009. Linguistik Umum: Sebuah Ancangan Awal Memahami Ilmu Bahasa. Jakarta:

Lembaga Penelitian UIN Jakarta.

Alwi, Hasan dkk. 2003. Tata Bahasa Baku Bahasa Indonesia. Jakarta: Pusat Bahasa dan Balai Pustaka.

Chaer, Abdul. 2009. Pengantar Semantik Bahasa Indonesia. Jakarta: Gajah Mada University Press.

Halliday, M.A.K, dan Hassan. 1985. Language, Context, and Text. Geolog Victoria: Deakin University Press.

Henry Guntur Tarigan. 1987. Pengajaran wacana. Bandung: Angkasa.

Hoed, B.H. 1994. "Wacana, Teks, dan Kalimat”. dalam Liberty P. Sihombing, dkk. (ed.), Bahasawan Cendekia.

Seuntai Karangan untuk Anton M. Moeliono, hlm. 125-135. Jakarta: Intermasa.

Johnstone, Barbara. 2008. Discourse Analysis. Massachusett: Blackwell Publishers.

Junaiyah dan E. Zaenal Arifin. 2008. Keutuhan Wacana. Jakarta: Grasindo.

Keraf, Gorys. 2005. Diksi dan Gaya Bahasa. Jakarta: Gramedia.

Kushartanti, dkk. 2007. Pesona Bahasa: Langkah Awal Memahami Linguistik. Jakarta: Gramedia Pustaka Utama.

Larson, Mildred L. 1984. Penerjemahan Berdasar Makna: Pedoman untuk Pemadanan Antarbahasa. Boston

Way: Summer Institute of Linguistics.

Mulyana. 2005. Kajian wacana. Yogyakarta: Tiara wacana.

Renkema, Jan. 1993. Discourse Studies: An Introductory Textbook. Amsterdam: John Benjamin Publishing

Company.

Renkema, Jan. 2004. Introduction to Discourse Studies. Edisi Kedua. Amsterdam/Philadelphia: John Benjamins Publishing Company.

Silviana, Irna. 2010. “Wacana Iklan Advertorial Kondom pada Media Massa Cetak Majalah Pria Dewasa dan Majalah Wanita Dewasa” Skripsi. Depok: Fakultas Ilmu Pengetahuan Budaya, Universitas Indonesia.

Sudaryanto. 1988. Metode Linguistik. Yogyakarta: Gadjah Mada University Press.

Verhar, J. W. M. 2001. Asas-Asas Linguistik. Yogyakarta: Gajah Mada University Press. 